\title{
PERUBAHAN PERMEABILITAS ZEOKERAMIK AKIBAT PENAMBAHAN ABU SEKAM PADI
}

\author{
Changes of Zeoceramic Permeability as a Result of Rice Husk Ash \\ Addition
}

\section{PRIYO HARTANTO}

Pusat Penelitian Geoteknologi LIPI

Komplek LIPI Jl. Sangkuriang Bandung 40135

e-mail: hartanto@geotek.lipi.go.id

\begin{abstract}
ABSTRAK
Pertambahan penduduk menyebabkan meningkatnya kebutuhan perumahan yang mengakibatkan perubahan fungsi lahan terbuka menjadi tertutup. Alihfungsi lahan terbuka menjadi pemukiman mengakibatkan daya serap air ke dalam tanah menjadi terhambat, sehingga air mengalir di permukaan tanah dan mengakibatkan banjir. Untuk mengurangi masalah tersebut dapat digunakan zeokeramik yang dapat menyerap air. Zeokeramik dibuat dari zeolit, abu terbang, abu sekam padi, sebagai matriks bahan pengikat dan air. Zeolit merupakan agregat kasar yang mampu menyerap air. Abu terbang berfungsi sebagai perekat dan penguat campuran bahan sedangkan abu sekam padi (rice husk ash - RHA) berfungsi untuk menurunkan berat jenis dan membantu membentuk rongga-rongga pori bahan. Komponen utama dalam percobaan pembuatan zeokeramik yang dibuat sebagai parameter tetap adalah zeolit, abu terbang, bahan pengikat dan air masing-masing sebesar 9,75; 5; 2 dan 0,5 liter. Sebagai parameter berubah digunakan abu sekam padi yang ditambahkan sebesar 0,$25 ; 0,5 ; 0,75$ dan 1,00 liter. Prototipe zeokeramik dicetak menggunakan alat cetak tekan secara manual kemudian dikeringkan di oven pada $150^{\circ} \mathrm{C}$ selama 24 jam. Hasil pengujian tingkat permeabilitas zeokeramik dengan penambahan RHA menunjukkan kecenderungan naik dari 34,0 × $10^{-6}$ sampai $8,35 \times 10^{-5} \mathrm{~cm} /$ detik. Hasil yang paling optimum adalah pada penambahan abu sekam padi 0,75 liter yaitu sebesar $8,35 \times 10^{-5} \mathrm{~cm} /$ detik. Pada penambahan abu sekam padi di atas 0,75 liter permeabilitas zeokeramik cenderung menurun. Korelasi antara permeabilitas dengan sifat fisik zeokeramik menunjukkan bahwa komposisi penambahan 0,75 liter RHA mempunyai sifat fisik yang paling ideal dengan nilai permeabilitas paling baik yaitu sebesar $8,35^{-5} \mathrm{~cm} /$ detik. Penggunaan zeokeramik ini dapat mengurangi air larian dan semakin banyak air yang meresap ke dalam tanah.
\end{abstract}

Kata kunci: zeokeramik, permeabilitas, bahan bangunan, bata-beton, Abu Sekam Padi (RHA)

\begin{abstract}
Population growth bad to increase the demand of housing that resulted the changes in the function of open space to be the close one. Conversion of the open space to settlements results in blocking the water absorption into the soil, so the water runs on the surface and causes flood. To reduce the problem, a kind of paving blocks called zeoceramic can be used to adsorb water. Zeoceramic is made from zeolite. Fly ash, rice husk ash (RHA) and water are used as binder materials. Zeolite is a coarse aggregate that is able to adsorb water while fly ash has a function as an adhesive and strengthener the mixture. RHA serves to reduce specific gravity and helps forming the cavities pores. The fixed parameters in making zeoceramic were 9.75 liters of zeolite, 5 liters of fly ash, 2 liters of binder and 0.5 liters of water. As the variable, the RHA was added to the mixture for $0.25 ; 0.5 ; 0.75$ and 1.00 liters, respectively. Zeoceramic prototype was molded manually using compression molding tools and then dried in an oven at $150^{\circ} \mathrm{C}$ for 24 hours. The results showed that zeoceramic permeability with RHA addition has $34.0 \times 10^{-6}$ to $8.35 \times 10^{-5} \mathrm{~cm} / \mathrm{sec}$. The optimum result is achieved at 0.75 liters. RHA addition showing permeability of $8.35 \times 10^{-5} \mathrm{~cm} / \mathrm{sec}$. The RHA addition above 0.75 liters results in decreasing zeoceramic permeability. The use of this zeoceramic would reduce water runoff and more water can penetrate the ground soil.
\end{abstract}

Keywords: zeoceramic, permeability, building materials, paving block, rice husk ash (RHA) 


\section{PENDAHULUAN}

Meningkatnya pertumbuhan penduduk diikuti dengan naiknya kebutuhan perumahan serta alihfungsi lahan pertanian atau lahan terbuka menjadi permukiman. Seperti yang terjadi di Jawa Barat, beberapa daerah Bandung dan Kabupaten Bandung lahan pertanian berkurang sebagai akibat alihfungsi lahan menjadi daerah hunian yang berakibat kepada terjadinya krisis air (Darwis, 2010). Krisis air ini diperparah oleh rusaknya lingkungan, terutama akibat permukaan tanah yang makin tidak memungkinkan terserapnya air hujan yang turun ketika musimnya tiba. Secara alami jumlah air hujan dari dulu hingga sekarang sama dan musim hujan adalah waktu yang tepat untuk mengatasi krisis air (Bakar, 2006). Rendahnya daya serap tanah terhadap air hujan terjadi karena kurangnya permukaan tanah terbuka hijau akibat habis dibangun untuk rumah dan gedung-gedung. Alihfungsi lahan terbuka menjadi pemukiman mengakibatkan penurunan daya serap air ke dalam tanah.

Beberapa kegiatan penambangan, kerajinan bata merah dan PLTU akan menghasilkan limbah padat. Limbah padat (waste) sisa kegiatan penambangan zeolit di daerah Sukabumi cukup melimpah. Industri genteng di Sukabumi dan Palimanan Cirebon menghasilkan limbah padat yang disebut 'samod'. Kerajinan batamerah banyak menghasilkan abu sekam padi (Rice Husk Ash/RHA). Pembangkit listrik tenaga uap (PLTU) dengan bahan bakar batubara menghasilkan abu terbang (fly ash). Limbah padat tersebut belum dimanfaatkan secara optimal, sehingga menjadi peluang untuk menghasilkan suatu produk baru seperti zeokeramik.

Peranan batubara dalam penyediaan energi nasional akan diikuti masalah lingkungan karena hasil pembakaran batubara menghasilkan 5\% polutan padat berupa abu, baik abu terbang maupun abu dasar (Wardani, 2008). Pemanfaatan abu terbang di bidang teknik sipil dapat meningkatkan stabilitas tanah sekaligus memberikan nilai tambah abu tersebut. Penelitian ini menggunakan limbah kegiatan penambangan, sehingga mungkin masih mengandung unsur berbahaya. Wardani (2008) menyebutkan bahwa memanfaatkan limbah abu terbang untuk keperluan bahan bangunan belum dimasyarakatkan secara optimal, karena berdasarkan PP. No.85 tahun 1999 tentang pengelolaan limbah bahan berbahaya dan beracun (B3), abu terbang dan abu dasar dikategorikan sebagai limbah B3 karena terdapat kandungan oksida logam berat yang akan mengalami pelindian secara alami yang dapat mencemari lingkungan. Percobaan Sumarnadi (2007) menunjukkan bahwa zeolit sebagai matriks menghasilkan nilai bobot isi relatif ringan, yakni sekitar $1,3-1,4 \mathrm{~kg} / \mathrm{cm}^{3}$, demikian juga dengan penambahan abu sekam padi (RHA) menunjukkan bobot isi yang ringan. Penggantian semen dengan abu batubara sampai 30\% dari berat semen mampu meningkatkan nilai kuat tekan, namun penggantian di atas 30\% akan menurunkan kuat tekan (Sutarno dan Sukardi, 2008). Penambahan sekam padi yang mutunya baik dapat menurunkan panas hidrasi semen pada proses campuran beton sehingga dengan panas hidrasi yang rendah dapat mencegah retak-retak yang akan timbul (Ikabali dan Prakoso, 2002).

Prototipe zeokeramik yang berupa paving-block ini menjadi pilihan dalam penelitian, karena bahan ini banyak menjadi pilihan pengembang dan masyarakat untuk pengerasan jalan lingkungan, pelataran parkir perumahan maupun taman. Untuk menghasilkan zeokeramik, diperlukan pencontoh limbah padat yang diambil di lapangan. Pencetakan dilakukan untuk menghasilkan prototipe berupa paving block. Prototipe tersebut kemudian diuji permeabilitasnya untuk mengetahui sampai sejauh mana kemampuan meluluskan zat cair melalui poripori zeokeramik.

Penelitian zeokeramik ini menjadi penting karena dapat digunakan untuk bangunan alternatif yang mampu meningkatkan daya serap air ke dalam tanah pada lahan yang diperkeras. Selain itu penelitian ini menggunakan limbah padat dari hasil kegiatan penambangan dan PLTU yang berguna untuk menopang pengembangan permukiman. Zeokeramik yang dihasilkan berupa paving block atau bata ringan hasil perpaduan antara zeolit sebagai matrik dan bahan pengikat lain. Dihasilkannya zeokeramik diharapkan dapat memberikan salah satu solusi dalam meningkatkan kemampuan meresapnya air ke dalam tanah akibat perkerasan lahan oleh bangunan. Penelitian zeokeramik ini bertujuan memberi solusi pemanfaatan limbah kegiatan penambangan, industri batamerah maupun pemanfaatan limbah abu terbang. Selain itu, pemanfaatan limbah padat tersebut diharapkan dapat mengurangi material buangan dan menekan kerusakan lingkungan.

\section{METODE}

Bahan baku utama zeokeramik adalah zeolit dan abu terbang. Kedua bahan tersebut merupakan 
limbah sisa penambangan zeolit dan sisa pembakaran batubara di PLTU. Pemilihan zeolit didasari oleh sifatnya yang memiliki rongga dan ukuran pori tertentu yang mampu menyerap air sebanyak 25,93\% (Estiaty dan Sumarnadi, 2003). Zeolit yang digunakan berukuran: $(-4+8) ;(-8+16) ;(-16+30)$; $(-30+50) ;(-50+100) ;(-100+200)$ dan $(-200)$ mesh. Sebagai bahan pengisi digunakan RHA (Arifin dan Hartanto, 2011) karena kaya akan kandungan silika, mampu meningkatkan kuat tekan paving block dan menurunkan persentase serapan air (Suparti dkk, 2008). Pemanfaatan limbah padat untuk membuat paving-block biasanya ditambahkan dengan penambahan bahan pengikat. Bahan pengikat yang umum digunakan adalah portland cement (PC) dan water glass (WG), karena kedua bahan bila dicampur dengan air dapat berfungsi sebagai pengikat (Sumarnadi, 2007). Peralatan untuk mencetak prototipe zeokeramik menggunakan alat cetak tekan manual berukuran standard (Gambar 1) kemudian dikeringkan di oven pada suhu $150^{\circ} \mathrm{C}$ selama 24 jam.

Terdapat 2 (dua) metode untuk menentukan nilai permeabilitas (k) di laboratorium. Pertama adalah constan head permeameter yang digunakan untuk tanah yang nilai permeabilitasnya tinggi $\left(k>10^{-3}\right.$ $\mathrm{cm} /$ detik). Sementara untuk nilai permeabilitas kecil ( $k 10^{-3} \mathrm{~cm} /$ detik) digunakan falling head permeameter. Untuk pengujian zeokeramik ini digunakan metode yang kedua yaitu falling head permeameter dengan alat ukur permeameter jenis falling head (Gambar 2).

Benda uji berupa zeokeramik dicetak dengan komposisi seperti pada Tabel 1. Formula yang dipakai dengan rasio antara padatan/cairan adalah 5/1 dan

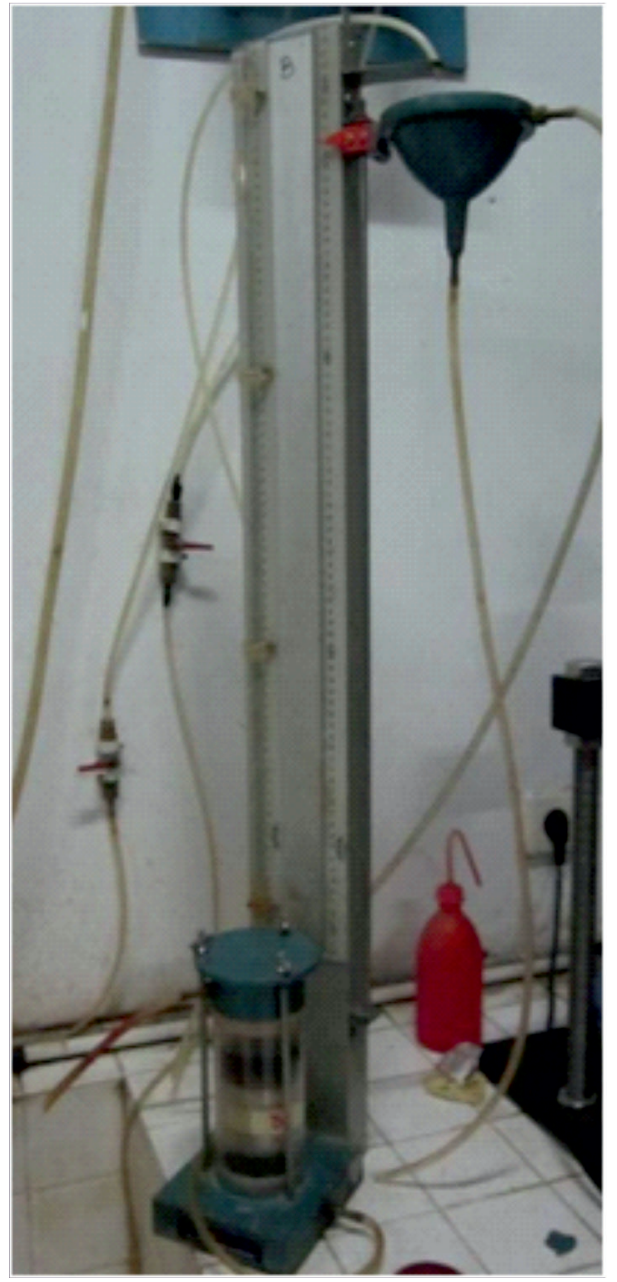

Gambar 2. Permeameter jenis falling head

perbandingan bahan pengikat/air sebesar 4/1 menghasilkan sifat fisik dan mekanik yang cukup baik (Sumarnadi, 2007). Selain itu, bata keramik berbahan
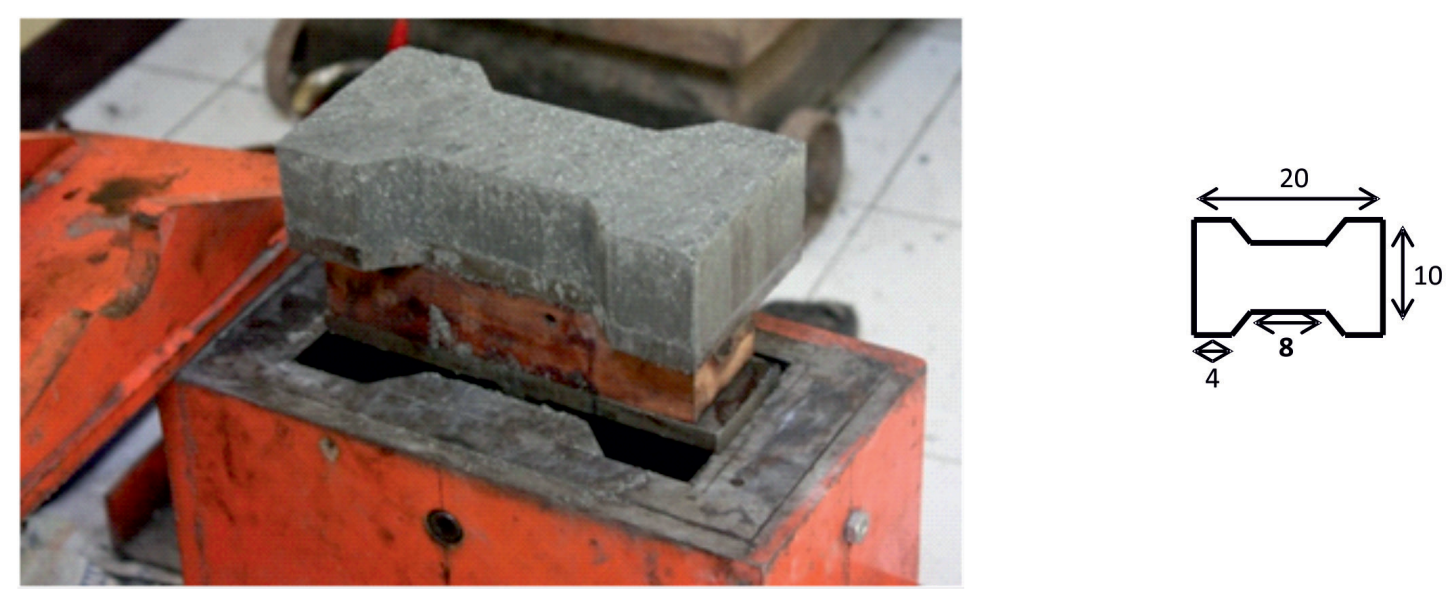

Gambar 1. Alat cetak tekan manual dan ukuran paving block (dalam cm) 
Tabel 1. Komposisi bahan uji zeokeramik jenis paving block*)

\begin{tabular}{|c|c|c|c|c|c|c|c|c|}
\hline \multirow{2}{*}{ No } & \multirow{2}{*}{ Kode } & \multirow{2}{*}{$\begin{array}{c}\text { Matriks } \\
\text { Zeo }\end{array}$} & \multicolumn{2}{|c|}{ Filler } & \multicolumn{2}{|c|}{ Liquid } & \multicolumn{2}{|c|}{ Rasio } \\
\hline & & & FA & RHA & $\mathrm{BP}$ & air & $\mathrm{S} / \mathrm{L}$ & BP/air \\
\hline 1 & $\mathrm{X} 1$ & 9,75 & 5 & 0,25 & 2 & 0,5 & $6,0 / 1$ & $4 / 1$ \\
\hline 2 & $\mathrm{X} 2$ & 9,75 & 5 & 0,50 & 2 & 0,5 & $6,08 / 1$ & $4 / 1$ \\
\hline 3 & $\mathrm{X} 3$ & 9,75 & 5 & 0,75 & 2 & 0,5 & $6,18 / 1$ & $4 / 1$ \\
\hline 4 & $X 4$ & 9,75 & 5 & 1,0 & 2 & 0,5 & $8,28 / 1$ & $4 / 1$ \\
\hline
\end{tabular}

baku agregat pada umumnya mempunyai kemampuan untuk meloloskan air (Sumarnadi dkk., 2002). Perbandingan masing-masing bahan baku dan campuran lain digunakan ukuran volume dalam liter.

\section{HASIL DAN PEMBAHASAN}

Permeabilitas merupakan kemampuan zat cair untuk mengalir melalui bahan berpori. Sifat permeabilitas tanah dipengaruhi oleh ukuran pori, jenis tanah/batu dan kepadatannya yang dinyatakan dengan nilai k. Untuk mengetahui sifat permeabilitas zeokeramik yang digunakan sebagai paving block bagi perkerasan lahan, maka sifat permeabilitasnya dibandingkan dengan nilai permeabilitas tanah. Sifat tanah berdasarkan nilai permeabilitas $(k)$ seperti pada Tabel 2 (Verruijt, 2001):

Hasil pengukuran permeabilitas menggunakan falling-head permeameter menunjukkan bahwa dengan penambahan abu sekam padi (rice husk ash/RHA) antara 0,25 sampai 1 liter menunjukkan nilai $\mathrm{k}$ antara $8,35 \times 10^{-5}$ sampai $3,0 \times 10^{-6} \mathrm{~cm} /$ detik. Berdasar tingkat permeabilitas seperti klasifikasi yang dijelaskan oleh Verruijt (2001) pada Tabel 2 di atas, zeokeramik komposisi $\mathrm{X}_{1}, \mathrm{X}_{2}$ dan $\mathrm{X}_{4}$ termasuk dalam kategori very-low permeability sedangkan komposisi $X_{3}$ yang memiliki nilai $\mathrm{k} 8,35 \times 10^{-5} \mathrm{~cm} /$ detik mendekati kategori low permeability. Grafik yang menunjukkan perubahan nilai permeabilitas (k) terhadap penambahan RHA disajikan pada Gambar 3. Untuk keperluan pembanding tingkat permeabilitas zeokeramik dilakukan juga pengukuran nilai $k$ terhadap zeokeramik tanpa penambahan RHA (Percontoh B). Zeokeramik tanpa penambahan RHA dengan matriks halus memiliki nilai $k$ $6,85 \times 10^{-6} \mathrm{~cm} /$ detik. Ini menunjukkan bahwa nilai k zeokeramik tanpa penambahan RHA dalam kategori very-low permeability.

Sebagai pembanding dilakukan pula pengukuran permeabilitas zeokeramik yang tidak dicampur bahan RHA dan paving-block dengan komposisi pasir dan semen. Hasil pengukuran tingkat permeabilitas zeokeramik tanpa RHA dengan matriks kasar memiliki nilai k 5,02×10 $0^{-5} \mathrm{~cm} /$ detik (low-very low permeability). Begitu juga untuk zeokeramik tanpa RHA dengan matriks halus memiliki nilai $k$ $6,85 \times 10^{-6} \mathrm{~cm} /$ detik. Zeokeramik tanpa RHA dan

Tabel 2. Jenis tanah berdasar tingkat permeabilitas (Verruijt, 2001)

\begin{tabular}{|c|c|c|}
\hline Jenis Tanah & Nilai k (cm/detik) & Nama \\
\hline Kerikil & $>10^{-1}$ & High permeability \\
\hline Kerikil halus/pasir & $10^{-1}-10^{-3}$ & Medium permeability \\
\hline $\begin{array}{l}\text { Pasir sangat halus/ } \\
\text { Pasir lunak } \\
\text { Lanau tidak padat }\end{array}$ & $10^{-3}-10^{-5}$ & Low permeability \\
\hline $\begin{array}{l}\text { Lanau padat } \\
\text { Lanau lempung } \\
\text { Lanau tidak murni }\end{array}$ & $10^{-5}-10^{-7}$ & Very low permeability \\
\hline Lempung & $<10^{-7}$ & Imprevious \\
\hline
\end{tabular}




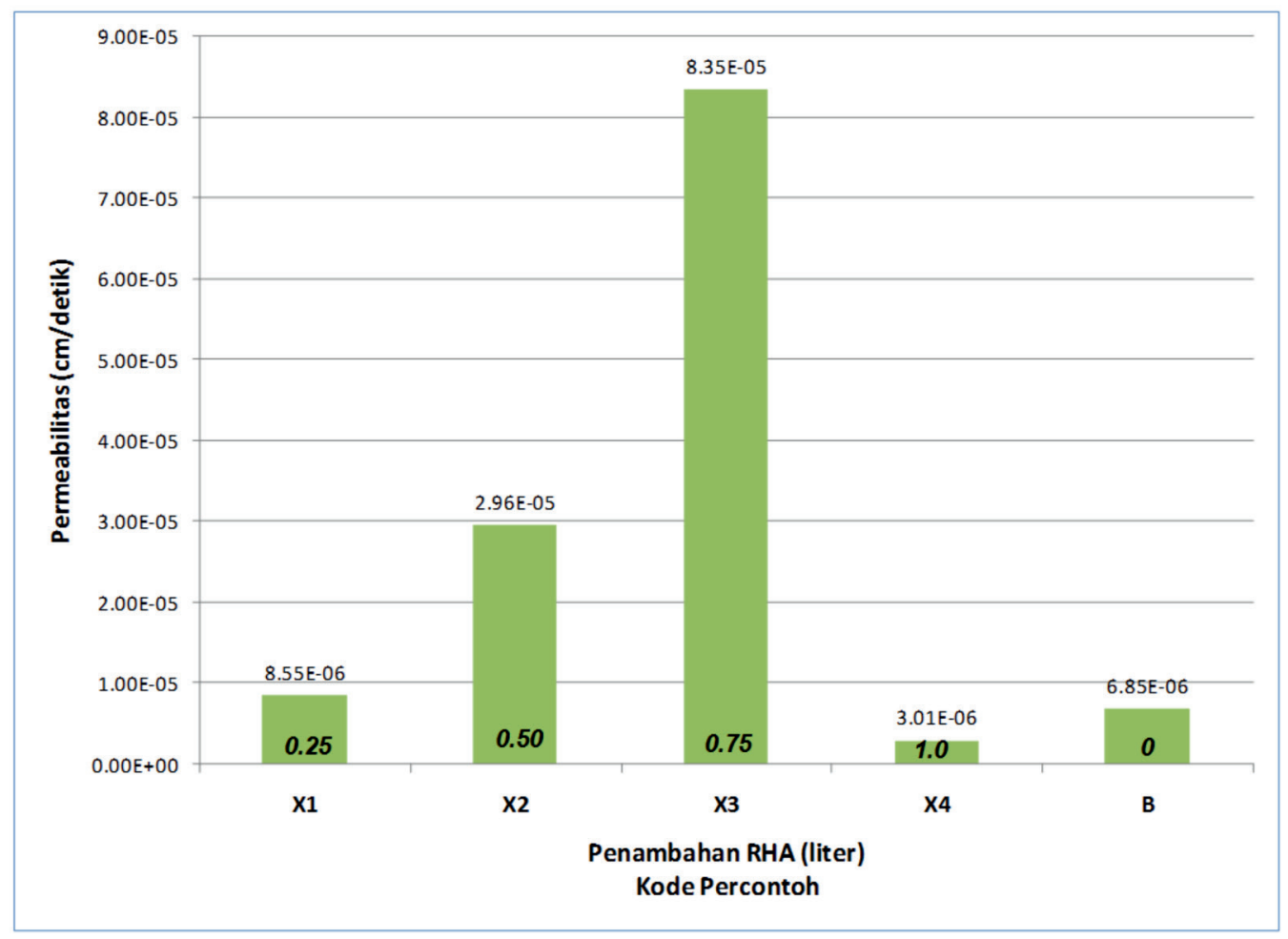

Gambar 3. Hasil pengujian nilai permeabilitas (k) terhadap penambahan volume RHA

paving-block dengan komposisi pasir dan semen

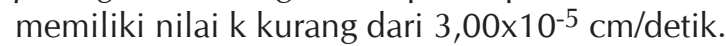

Hasil pengujian zeokeramik tanpa tambahan RHA yang mempunyai nilai permeabilitas paling baik adalah Percontoh $\mathrm{A}$, yaitu zeokeramik matriks

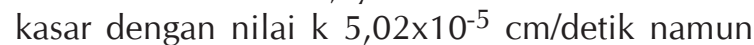
akan memiliki nilai $\mathrm{k}$ yang sangat kecil (very-low permeability) yaitu k $6,85 \times 10^{-6} \mathrm{~cm} /$ detik apabila menggunakan matriks halus (Percontoh B). Zeokeramik tanpa tambahan RHA dengan matriks campuran (Percontoh C) masih termasuk dalam kategori very-low permeability dengan nilai $\mathrm{k}$ $3,00 \times 10^{-5} \mathrm{~cm} /$ detik. Hal yang sama terjadi pada hasil pengujian terhadap paving block dari pabrik dengan campuran pasir dan semen (Percontoh BT) Percontoh tersebut masuk dalam kategori very-low

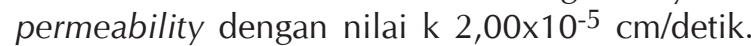
Hasil pengujian permeabilitas seluruh Percontoh baik dengan penambahan RHA dan pembandingnya berupa zeokeramik tanpa penambahan RHA terlihat pada Gambar 4.

Untuk pengerasan lahan apabila menggunakan zeokeramik, komposisi terbaik adalah zeokeramik dengan penambahan RHA 0,75 liter yang menghasilkan nilai permeabilitas sebesar $8,35 \times 10^{-5} \mathrm{~cm} /$ detik. Untuk meningkatkan kemampuan peresapan air ke dalam tanah pemasangan paving block, perlu dilakukan dengan cara seperti pada Gambar 5. Hal ini dimaksudkan memberi ruang kepada paving block untuk mengembang dan ada media sehingga air dapat masuk ke dalam tanah. Contoh pemasangan paving block seperti Gambar 5 terdapat di Sanders Garden World dekat Bristol, Inggris (Scholz and Grabowiecki, 2007).

Persyaratan fisik paving-block menurut SNI 030691-1996 paling tidak memiliki nilai penyerapan air, ketahanan aus dan kuat tekan yang disyaratkan Tabel 3.

Untuk mengetahui sifat fisik zeokeramik yang memenuhi syarat agar bisa digunakan, telah dilakukan beberapa uji fisik antara lain: sifat kuat tekan, keausan, berat jenis, kadar air dan penyerapan air terhadap benda uji. Nilai permeabilitas zeokeramik dengan penambahan RHA masing 0,25; 0,50 dan 0,75 liter apabila dikaitkan dengan nilai kuat tekan menunjukkan kuat tekan lebih dari 15,67 MPa sehingga masih memenuhi syarat untuk pelataran parkir (perumahan). Namun, bila dilihat dari nilai permeabilitas, zeokeramik dengan penambahan 0,75 liter RHA mempunyai permeabilitas paling baik yaitu $8,35 \times 10^{-5} \mathrm{~cm} /$ detik dan masuk dalam klasifikasi low permeability (Verruijt, 2001). 


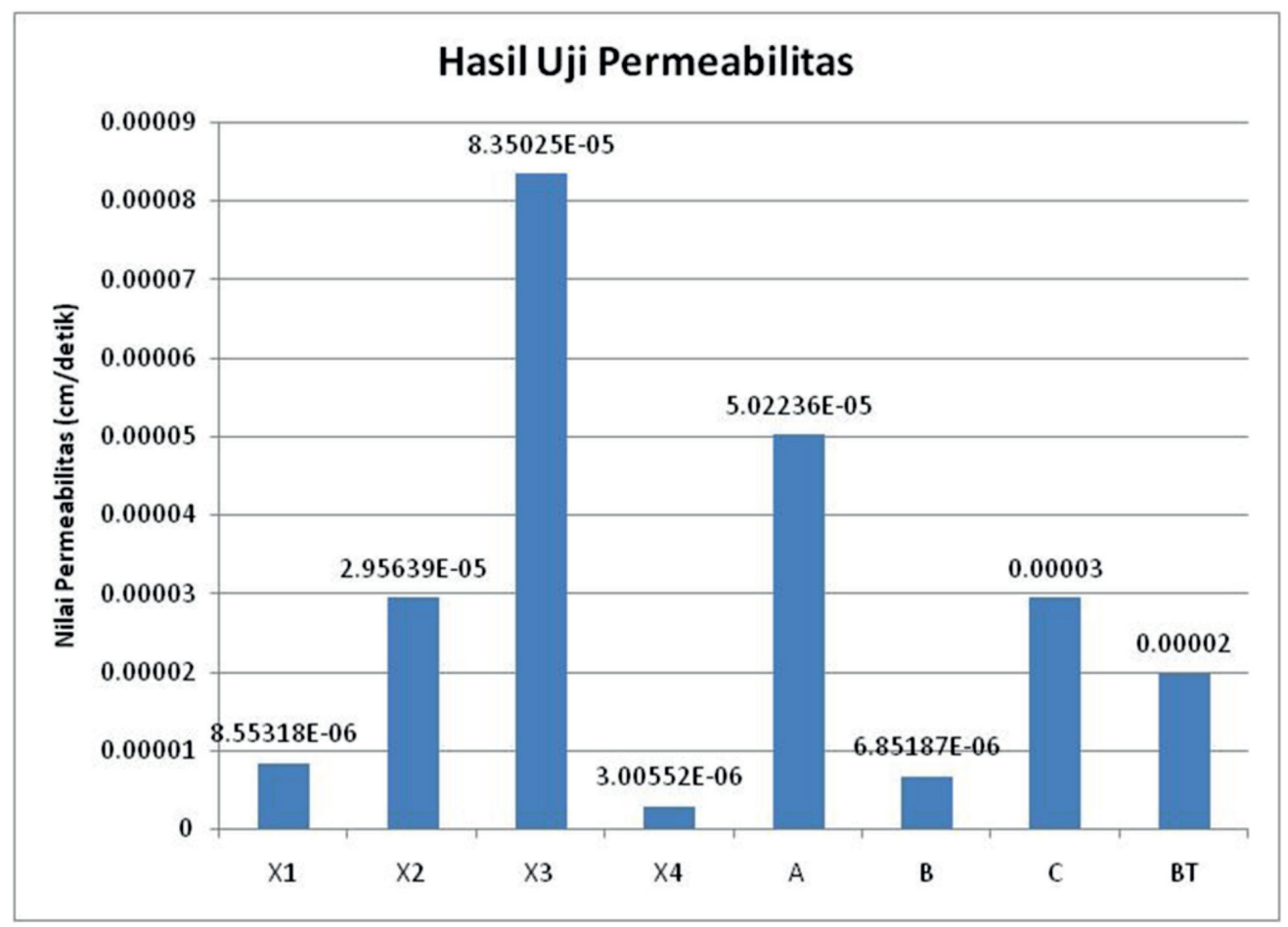

Keterangan:

$\mathrm{X}_{1}$ : Zeokeramik ditambah 0,25 liter RHA

A : Zeokeramik tanpa RHA matriks kasar

$\mathrm{X}_{2}$ : Zeokeramik ditambah 0,50 liter RHA

B : Zeokeramik tanpa RHA matriks halus

$\mathrm{X}_{3}$ : Zeokeramik ditambah 0,75 liter RHA

C : Zeokeramik tanpa penambahan RHA

$\mathrm{X}_{4}$ : Zeokeramik ditambah 1,00 liter RHA

BT : Paving-block pabrik

Gambar 4. Hasil pengujian nilai permeabilitas (k) terhadap ragam paving-block
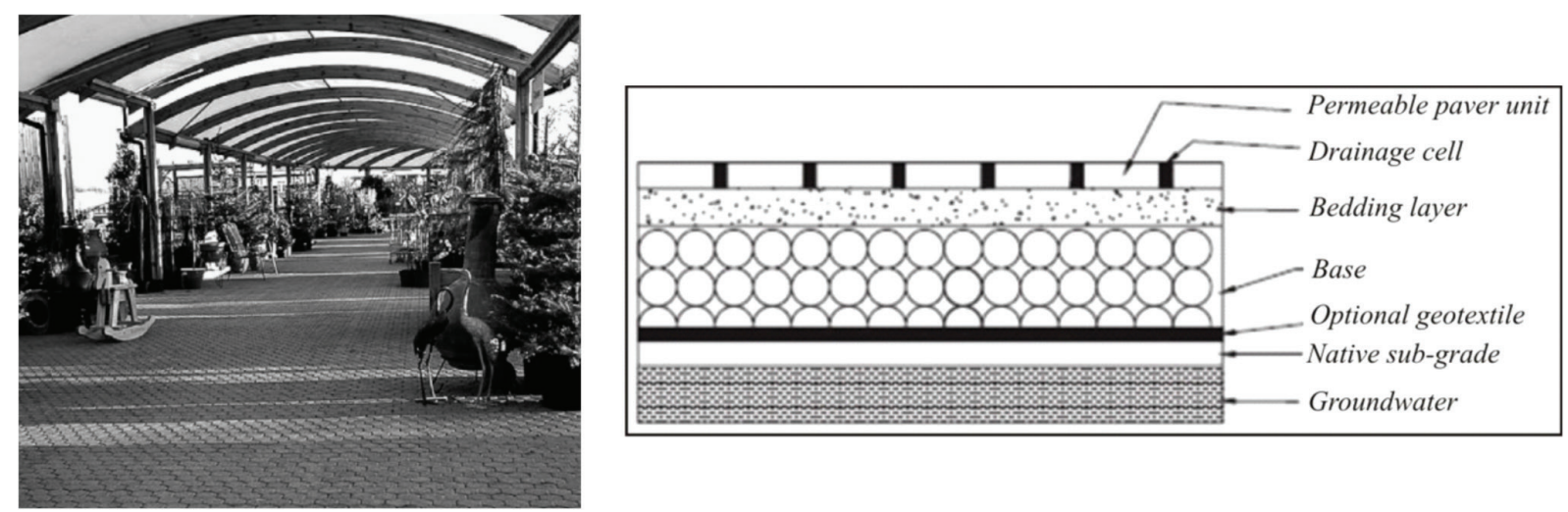

Gambar 5. Penampang pemasangan paving-block (Scholz and Grabowiecki, 2007)

Sementara itu, zeokeramik dengan penambahan 1 liter $\mathrm{RHA}\left(\mathrm{X}_{4}\right)$ nilai kuat tekannya adalah 7,58 MPa. Rendahnya nilai kuat tekan ini kemungkinan disebabkan oleh kelebihan campuran RHA, seperti hasil pengujian Budi, dkk (2002) yang menunjukkan bahwa semakin banyak persentase abu sekam padi semakin menurunkan kekuatan tanah. Penambahan abu sekam padi yang paling baik maksimum
$30 \%$. Penambahan sekam padi yang mutunya baik dapat menurunkan panas hidrasi semen pada proses campuran beton sehingga dengan panas hidrasi yang rendah dapat mencegah retak-retak yang akan timbul karenanya (Ikabali dan Prakoso, 2002). Gambar 6 menunjukkan hubungan antara permeabilitas dan kuat tekan zeokeramik terhadap penambahan RHA. 
Tabel 3. Persyaratan fisis paving-block (menurut SNI 03-0691-1996)

\begin{tabular}{ccccccl}
\hline \multirow{2}{*}{ Mutu } & \multicolumn{1}{c}{ Kuat tekan (MPa) } & Ketahanan aus $(\mathrm{mm} /$ menit) & $\begin{array}{c}\text { Penyerapan } \\
\text { air rata-rata } \\
\text { maks }\end{array}$ & Peruntukan \\
\cline { 2 - 6 } & rata-rata & min & rata-rata & maks & $\%$ & \\
\hline A & 40 & 35 & 0.090 & 0,103 & 3 & Jalan \\
B & 20 & 17,0 & 0,130 & 0,149 & 6 & Pelataran parkir (perumahan) \\
C & 15 & 12,5 & 0,160 & 0,184 & 8 & Pejalan kaki \\
D & 10 & 8,5 & 0,219 & 0,251 & 10 & Taman dan penggunaan lain \\
\hline
\end{tabular}

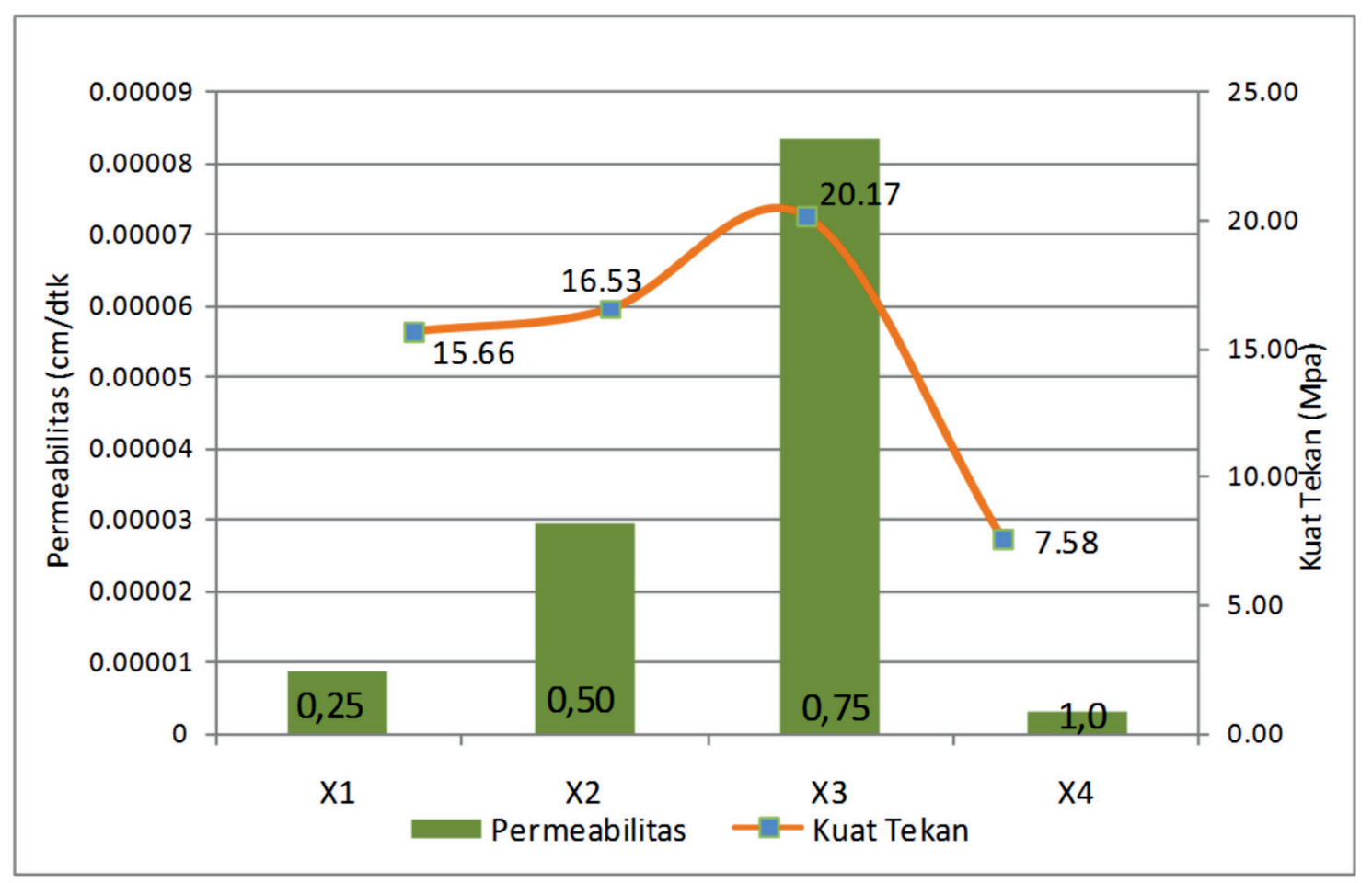

Gambar 6. Hubungan antara permeabilitas dan kuat tekan zeokeramik terhadap penambahan RHA

Penambahan volume RHA pada zeokeramik juga akan diikuti oleh penurunan berat jenis seperti pada Gambar 7.

Sementara itu penambahan RHA pada zeokeramik bila dilihat dari nilai permeabilitas dan keausan seperti terlihat pada Gambar 8.

Berdasarkan Gambar 8, hasil analisis permeabilitas terhadap zeokeramik dengan penambahan 0,75 liter RHA menunjukkan permeabilitas $8,35 \times 10^{-5}$ $\mathrm{cm} /$ detik dengan nilai keausan $0,125 \mathrm{~mm} / \mathrm{menit}$, disusul oleh zeokeramik dengan penambahan 0,50 liter RHA yang memiliki permeabilitas $2,96 \times 10^{-5}$ cm/detik dengan nilai keausan 0,095 mm/menit. Meskipun demikian, hasil pengujian keausan zeokeramik untuk komposisi $\mathrm{X}_{2}, \mathrm{X}_{3}$ dan $\mathrm{X}_{4}$ atau penambahan RHA masing-masing 0,50;0,75 dan 1 liter menunjukkan nilai keausan yang memenuhi syarat SNI (Arifin dan Hartanto, 2011). Komposisi $X_{1}$ atau penambahan 0,25 liter RHA memiliki nilai keausan hanya memenuhi peruntukan taman dan penggunaan lain. Abu sekam padi merupakan material kaya akan kandungan silika (Suparti dkk, 2008). Silika akan semakin meningkatkan daya tahan terhadap gesekan dari luar dan menyebabkan nilai keausan menjadi baik. Meskipun demikian semakin banyak persentase abu sekam padi cenderung menurunkan 


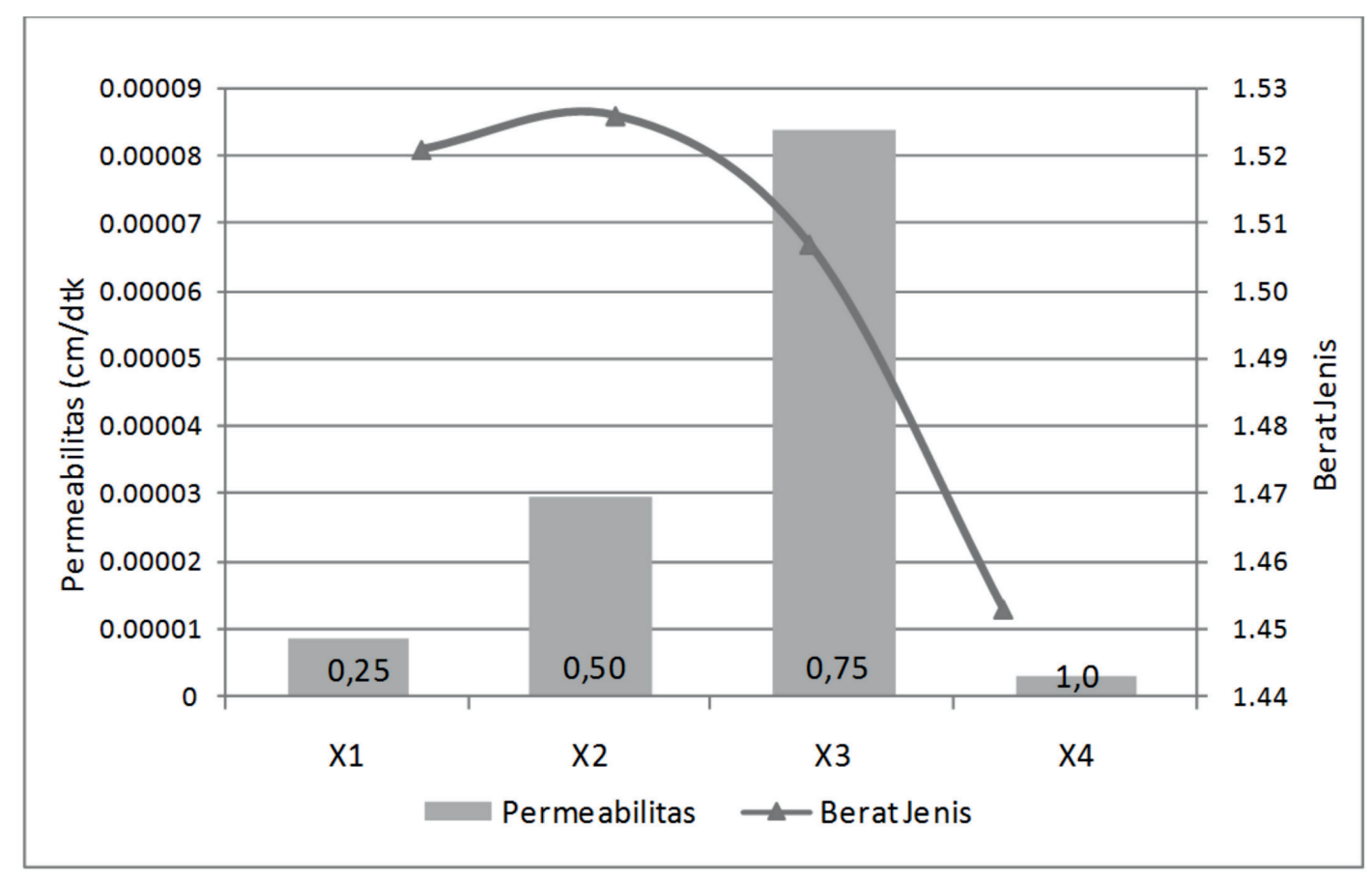

Gambar 7. Hubungan antara permeabilitas dan berat jenis zeokeramik terhadap penambahan RHA

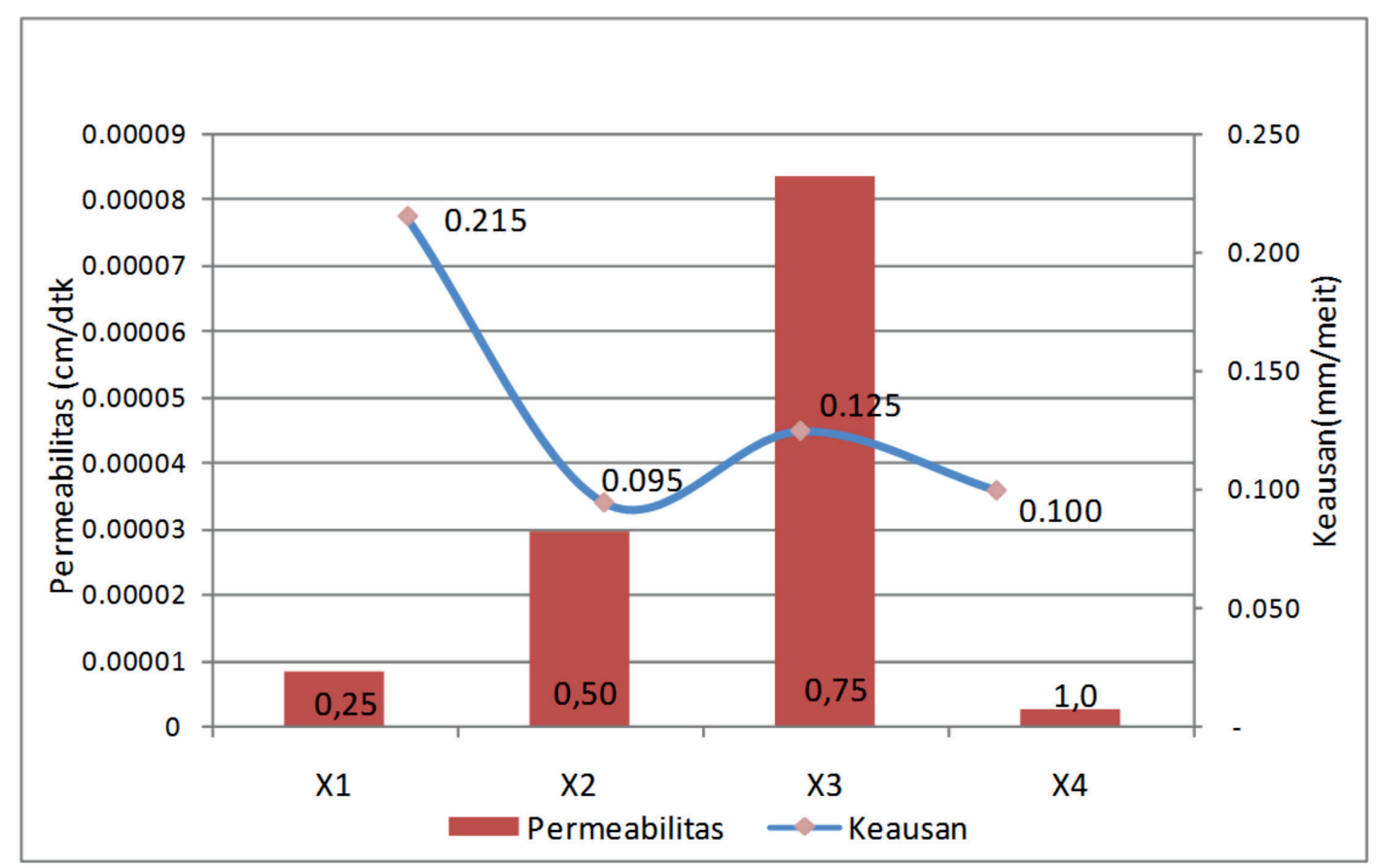

Gambar 8. Hubungan antara permeabilitas dan keausan zeokeramik terhadap penambahan RHA 
kekuatan tanah (Budi dkk., 2002).

Penambahan volume RHA pada zeokeramik berdasarkan persyaratan SNI 03-0691-1996 penyerapan air $10 \%$ hanya baik digunakan untuk taman dan penggunaan lain (Arifin dan Hartanto, 2011), sehingga hanya zeokeramik komposisi $\mathrm{X}_{4}$ yang layak digunakan untuk taman/penggunaan lain. Gambaran yang menunjukkan hubungan antara permeabilitas dan penyerapan air terhadap penambahan RHA pada zeokeramik seperti pada Gambar 9.

\section{KESIMPULAN}

Permeabilitas zeokeramik dengan penambahan 0,25 liter RHA memiliki nilai k 8,52-6 cm/detik. Penambahan 0,50 liter RHA memiliki nilai $\mathrm{k}$ sebesar $1,08^{-5} \mathrm{~cm} /$ detik. Zeokeramik dengan penambahan 0,75 liter RHA menghasilkan nilai k sebesar 8,35-5 $\mathrm{cm} /$ detik dan penambahan 1 liter RHA mempunyai nilai $\mathrm{k}$ sebesar $3,01^{-6} \mathrm{~cm} /$ detik. Komposisi $X_{3}$, yaitu zeokeramik dengan penambahan 0,75 liter RHA memiliki nilai $\mathrm{k}$ paling baik $\left(8,35^{-5} \mathrm{~cm} /\right.$ detik).
Permeabilitas zeokeramik dipengaruhi oleh rongga antar butir. Banyaknya air yang mampu meresap ke dalam tanah selain bukaan antar paving-block juga didukung oleh kemampuan zeokeramik meloloskan air ke dalam tanah. Besaran permeabilitas zeokeramik terbaik adalah dengan komposisi $X_{3}$. Hasil pengujian menunjukkan permeabilitas zeokeramik sebesar $8,35^{-5} \mathrm{~cm} /$ detik sehingga penggunaan zeokeramik dengan komposisi penambahan 0,75 liter RHA ini dapat mengurangi air larian dan semakin banyak air yang meresap ke dalam tanah.

Korelasi antara permeabilitas dengan sifat fisik zeokeramik menunjukkan bahwa hasil terbaik pada zeokeramik adalah dengan penambahan 0,75 liter RHA. Hasil pengujian menunjukkan bahwa material dengan komposisi tersebut mempunyai sifat fisik paling ideal dan nilai permeabilitas paling baik yaitu sebesar 8,35-5 cm/detik. Berdasarkan SNI 03-06911996, dilihat dari sifat kuat tekan komposisi $X_{1}, X_{2}$, $X_{3}$ dan $X_{4}$ memenuhi syarat untuk semua klasifikasi penggunaan. Dilihat dari sifat keausan komposisi $X_{1}$ hanya layak digunakan untuk taman/penggunaan lain sedangkan komposisi $\mathrm{X}_{2}$ dan $\mathrm{X}_{3}$ dapat untuk

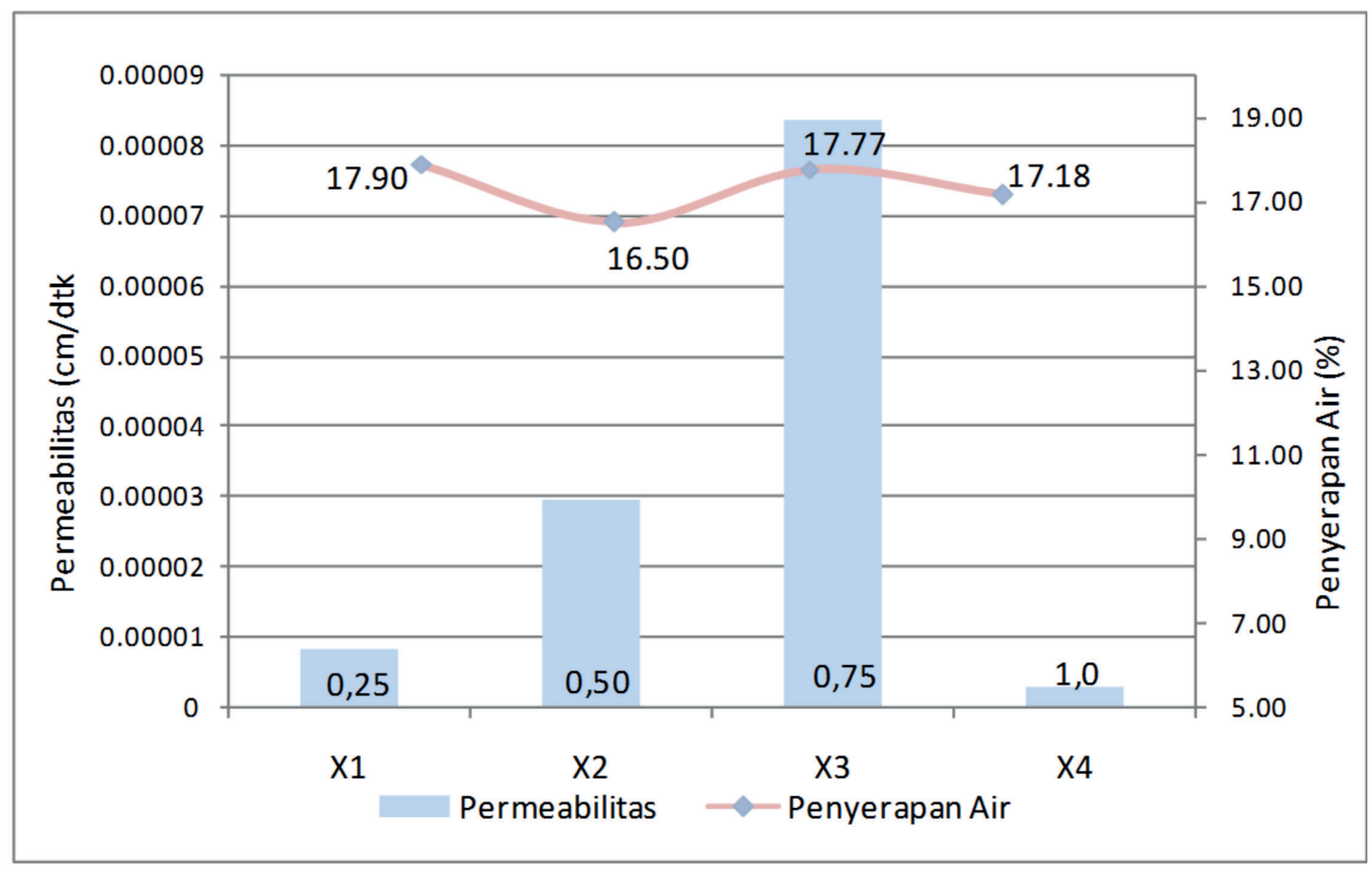

Gambar 9. Hubungan antara permeabilitas dan penyerapan air zeokeramik terhadap penambahan RHA 
pejalan kaki. Dari sisi penyerapan air, semua komposisi tidak layak digunakan untuk jenis apapun kecuali $\mathrm{X}_{4}$ yang layak digunakan untuk taman.

\section{UCAPAN TERIMAKASIH}

Penulis mengucapkan terimakasih kepada Danang Nor Arifin, ST dan rekan-rekan dari UPT Loka Uji Teknik Penambangan Jampang Kulon LIPI dalam menyiapkan prototipe. Terimakasih juga ditujukan kepada rekan-rekan di Laboratorium Geomekanik Pusat Penelitian Geoteknologi LIPI atas pengujian prototipe serta Ir. Eko Tri Sumarnadi, MT atas diskusi dan saran penyempurnaan tulisan ini. Penelitian ini dibiayai oleh DIPA UPT Loka Uji Teknik Penambangan Jampang Kulon LIPI tahun 2010 sampai 2011.

\section{DAFTAR PUSTAKA}

Arifin, D.N., dan Hartanto. P., 2011. Pengembangan zeokeramik sebagai bahan bangunan ramah lingkungan: klasifikasi mutu paving block berdasarkan SNI, Prosiding Pemaparan Hasil Penelitian Puslit Geoteknologi LIPI - 2011, ISBN : 978-979-863618-9, Bandung, hal 45-51.

Badan Standarisasi Nasional, SNI 03-0691-1996 Bata beton (paving block), http://websisni.bsn.go.id/ index.php?/sni main/sni/detail sni/1009, 22 Juni 2011, Jam 05. $\overline{47}$ PM.

Bakar, S., 2006. Krisis air tanah, Suara Karya Online, http://www.suarakarya-online.com/news. html? id = 142717, diakses 3 Desember 2012, Jam $09.25 \mathrm{AM}$.

Budi, G.S., Ariwibowo, D.S. dan Jaya, A.T., 2002. Pengaruh pencampuran abu sekam padi dan kapur untuk stabilitasi tanah ekspansif, Dimensi Teknik Sipil, Vol. 4, No. 2, hal 94-99, ISSN 1410-9530, Univ. Kristen Petra.

Darwis, S.N., 2010. Potret alih fungsi lahan di Jawa Barat, 11 Feb 2010, www.bataviase.co.id, diakses 14 November 2011, jam 9.39 PM.
Estiaty, L.M dan Sumarnadi, E.T., 2003. Zeolit alam sebagai matriks pembuatan lantai keramik: penelitian pendahuluan, RISET - Geologi dan Pertambangan, Jilid 13 No.1 Tahun 2003, hal. 65 - 75.

Ikabali dan Prakoso, A., 2002. Beton Abu sekam padi sebagai alternatif bahan konstruktif, Jurnal EMAS FT UKI, Tahun XII No. 29, Mei 2002, hal 75-81.

Scholz, M. dan Grabowiecki, P., 2007. Review of permeable pavement systems, Elsevier, Building and Environment 42 (2007) 3830-3836.

Sumarnadi, E.T., 2007. Bata keramik suhu bakar rendah sebagai bahan bangunan konstruksi ringan. Prosiding Seminar Geoteknologi, Konstribusi Ilmu Kebumian dalam Pembangunan Berkelanjutan, ISBN 978-979-799-255-5, Pusat Penelitian GeoteknologiLIPI, Bandung, hal: 197-206.

Sumarnadi, E.T, Sudaryanto dan Zulkarnaen, I., 2002. Agregat unggul berbahan baku lempung untuk konstruksi ringan. Prosiding Seminar Iptek Nuklir dan Pengelolaan Sumber Daya Tambang, ISBN: 979-8769-11-2, Batan, Jakarta, hal: 171-185.

Suparti, E., Damayanti, R.W. dan Pujiyanto, E., 2008. Penentuan setting level optimal pada pemanfaatan abu sekam padi untuk meningkatkan kualitas paving block menggunakan metode eksperimen Taguchi, Prosiding Seminar Nasional Teknoin, Bidang Teknik Industri.

Sutarno dan Sukardi., 2008. Peningkatan kuat tekan paving block dengan memanfaatkan abu batubara limbah industri, Wahana TEKNIK SIPIL, Vol. 13 No. 3, Desember 2008 hal 186-196, Universitas Diponegoro.

Verruijt, A., 2001, Soil mechanics, Delft University of Technology. 340 pp. http://geo.citg.tudelft.nl/ diunduh pada 27 Agustus 2012 jam 09.17 AM.

Wardani, S.P.R., 2008. Pemanfaatan limbah batubara (fly ash) untuk stabilisasi tanah maupun keperluan teknik sipil lainnya dalam mengurangi pencemaran lingkungan, Orasi Guru Besar, Fak. Teknik Undip, Semarang, 6 Desember 2008. 